\title{
Correlations between vascular invasion, neural structures invasion and microvessel density with clinicopathological parameters in gastric cancer
}

\author{
Corelaţii ale invaziei tumorale vasculare, invaziei în structurile neurale şi \\ densităţii microvascularizaţiei tumorale cu parametrii clinico-morfologici în \\ cancerul gastric
}

\begin{abstract}
Alina Bădescu' ${ }^{1}$, Claudia Valentina Georgescu ${ }^{2 *}, C^{2}$ laudiu Mărgăritescu ${ }^{3 * *}$, Daniela Cernea $^{4}$, Maria Bălăşoiu ${ }^{5}$, Ştefania Crăiţoiu ${ }^{6}$, Corneliu Cristian Georgescu ${ }^{7}$

1. University of Medicine and Pharmacy of Craiova, 2. Department of Pathology, Emergency County Hospital, Craiova, 3. Department of Pathology, University of Medicine and Pharmacy of Craiova, 4. Department of Intensive Care, University of Medicine and Pharmacy of Craiova, 5. Department of Microbiology- Immunology, University of Medicine and Pharmacy of Craiova, 6. Department of Histology, University of Medicine and Pharmacy of Craiova, 7. Department of Pharmacology,

University of Medicine and Pharmacy of Craiova
\end{abstract}

\begin{abstract}
Aim: Our objective in conducting this study was to estimate the presence of lymphatic, blood vessel and neural invasion on Hematoxylin \& Eosin (H\&E) staining and also, the microvessel density detected by immunohistochemistry (MVD), in gastric adenocarcinoma, as well as their relationship with the clinical, pathological and biological characteristics of the tumors. Materials and Methods: To assess the vascular and neural invasion in our study, we included 367 patients diagnosed with gastric cancer. For the immunohistochemical study of MVD, from all cases with gastric carcinoma, we selected 28 patients, 12 patients with gastric biopsy and 16 patients with total gastric resection, which established the TNM stage. All the gastric biopsies and surgical samples were prepared using the paraffin-embedding method and H\&E staining and using anti-CD31 and anti-CD34 antibodies for the assessment of intratumoral MVD. Results: The positive blood vessel invasion was associated in a significant way with advanced stages $(p<0.01)$ and high grade carcinomas $(p<0.01)$, while lymphatic invasion was very significant associated only with advanced stage tumors $(p<0.001)$. Regarding peri- and intraneural invasion, there was a significant matching with the female gender $(p<0.05)$, advanced stages of disease $(p<0.001)$, the diffuse type of gastric carcinoma $(p<0.05)$, and with poorly differentiated tumors $(p<0.05)$. There was a close relationship between CD34 MVD and the diffuse type of gastric carcinomas, according to Lauren's classification ( $p<0.05)$, and poorly differentiated tumors $(p<0.05)$. The CD34 MVD values mean was significant correlated with TNM stage,
\end{abstract}

*Corresponding author: Georgescu Claudia Valentina, Emergency County Clinical Hospital Craiova , e-mail: cgeorgescu2001@yahoo.com

** Author with equal contributions with the main authors 
especially III and IV stages ( $<<0.01)$. Conclusions: Blood vessel invasion, neural invasion and CD34 MVD play a significant role in tumors biological behavior and they can be used as important prognostic parameters which describes the aggressiveness of gastric carcinomas.

Keywords: gastric carcinoma, vascular invasion, neural invasion, MVD.

\section{Rezumat}

Scopul: Scopul studiului efectuat a fost acela de a estima prezenţa invaziei tumorale la nivelul vaselor limfatice, sanguine şi la nivel neural în carcinoamele gastrice pe preparatele colorate hematoxilină-eozină (H-E) şi, de asemenea, densitatea microvascularizatiei tumorale (MVD), detectată imunohistochimic, precum şi relaţia acestora cu parametrii clinico-patologici şi biologici ai tumorilor. Material şi metodă. Pentru evaluarea invaziei limfo-vasculare şi neurale am inclus în studiu 367 de pacienţi diagnosticaţi cu carcinoame gastrice. Pentru studiul imunohistochimic al MVD, au fost selectaţi 28 de pacienţi, din care 16 pacienţi cu gastrectomomie totală, în urma căreia s-a stabilit stadiul TNM al tumorii primare şi 12 pacienţi cu biopsie gastrică. Biopsiile gastrice şi probele chirurgicale au fost procesate folosind tehnica de includere la parafină şi coloraţia hematoxilină-eozină, iar pentru evaluarea imunohistochimică a MVD s-au utilizat anticorpii anti-CD31 şi anti-CD34. Rezultate: Prezenţa invaziei tumorale la nivelul vaselor sanguine a fost semnificativ asociată cu stadiile avansate de boală ( $p<0,01)$ şi cu carcinoamele gastrice slab diferenţiate $(p<0,01)$, in timp ce invazia vaselor limfatice s-a asociat semnificativ doar cu stadiul avansat al tumorilor $(p<0,001)$. In ceea ce priveşte invazia tumorală peri- sau intraneurală, s-a observat o corelaţie semnificativă a acesteia cu sexul feminin ( $p<0,05)$, cu stadiile avansate de boală $(p<0,001)$, cu tipul difuz al carcinoamelor gastrice $(p<0,05)$ şi cu tumorile slab diferenţiate $(p<0,05)$. S-a observat o legătură strânsă intre valoarea MVD determinată cu anticorpul anti CD34 şi doi dintre parametrii histopatologici importanţi: tipul histologic al carcinoamelor gastrice conform clasificării Lauren (tipul difuz; $p<0,05$ ) şi gradul de diferenţiere al tumorilor (tumorile slab diferenţiate; $p<0,05$ ). S-a observat de asemenea o corelaţie semnificativă a valorii medii a microdensităţii vasculare (MVD) evaluate cu CD34 şi stadiul TNM, in special cu stadiile III/IV ( $p<0,01)$. Concluzii: Invazia tumorală la nivelul vaselor sanguine, invazia neurală şi microdensitatea vasculară determinată cu CD34, joacă un rol major în comportamentul biologic al tumorilor şi pot fi utilizaţi ca factori prognostici importanţi, referitor la agresivitatea carcinoamelor gastrice.

Cuvinte cheie: carcinom gastric, invazie vasculară, invazie neurală, microdensitate vasculară (MVD).

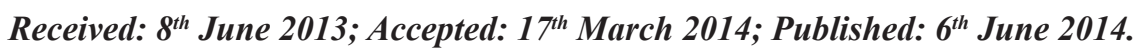

\section{Introduction}

Gastric carcinoma is a fairly prevalent malignancy worldwide, representing the second leading cause of death secondary to cancers [1]. Despite recent medical advances, the outcome secondary to gastric cancer remains discouragingly and the survival rate of advanced disease stages is decreased. Therefore, by improving the knowledge related to the complex molecular mechanisms which regulates the progression and aggressiveness of the gastric carcinoma, we can also descover new therapeutic approaches of this malignancy $[2,3]$.
Vascular invasion is one of the most important clinocopathological characteristics of malignant tumors. The presence of tumor invasion into the vessels is associated with a greater risk of lymph node and distant metastasis and a decrease in survival rate of patients with advanced disease [4].

In classical previous studies, vascular invasion estimated with hematoxylin-eosin staining has been defined either by the presence of tumor cells with fibrin clots, erythrocytes, or both in endothelial cell-lined spaces without erythrocyte extravasations in the surrounding tissues, or by the detection of tumor cells within smooth muscle cell-lined spaces [5]. 
Neural invasion represents a different pathological entity consisting of neoplastic invasion of nerves, both intraneural and perineural, which may be noticed independent to the absence of vascular or lymphatic invasion, and sometimes being the only way of spreading as tumor metastasation [6]. The perineural invasion is pretty common in various cancers such as head and neck cancer, pancreatic cancer or the prostate cancer [7].

Angiogenesis represents the process of formation new blood vessels and plays a very important role in survival of cancer cells, being a complex phenomen essential for the growth of solid tumors which are only a few millimeters and to the development of distant metastasis [8]. It is quite difficult to develop just one method capable of detecting such a complex biological function. Currently, the quantification of microvessel density (MVD) of tumors represents the most common method to asses angiogenesis, and is made using specific markers for endothelial cells, CD31, CD34 or factor VIII-related antigen [9-12].

Our objective in conducting this study was to estimate the presence of lymphatic, blood vessel and neural invasion on H\&E staining, and the micro-vascularization detected with antibodies against CD31 and CD34 in the primary gastric carcinoma as well as their relationship with the clinical, pathological and biological characteristics of the tumors.

\section{Materials and Methods}

For the assessment of vascular and perineural invasion, this study was conducted on 367 patients diagnosed with gastric carcinoma. This tissue came from patients hospitalized in the Clinics of Gastroenterology, Internal Medicine and Surgery of the Emergency County Hospital Craiova, during 2005-2011, and diagnosed with gastric cancer after performing upper gas- trointestinal endoscopy with sampling biopsies, which were followed by curative surgical approaches. For the immunohistochemical study of MVD, we selected 28 patients with gastric carcinoma, 16 patients with total gastric resection, which established the TNM stage, and 12 patients, included right after the gastric biopsy made through upper digestive endoscopy, which confirmed the diagnosis of gastric carcinoma. For the TNM staging, the M category was established through the following methods: chest radiography, transabdominal ultrasound, computed tomography for thorax, abdomen and pelvis, and exploratory laparotomy because all patients underwent gastric surgery with curative or palliative intent.

All the gastric biopsies and surgical samples were prepared for routine neutral buffered formalin fixation and paraffin embedding technique. The $5 \mu \mathrm{m}$ sections were stained initially with Hematoxylin \& Eosin. On H\&E sections the tumors were classified as diffuse, intestinal or unclassified tumors (others types), according to Lauren classification [13]. All tumors, except those of the diffuse type, were graded as well differentiated (G1), moderately differentiated (G2) or poorly differentiated (G3). Tumor invasion into the veins, arteries and lymphatics vessels or into the perineurium or neural fascicles was assessed histologically in the representative H\&E section and graded as absent or present.

For the immunohistochemical evaluation of the tumor neoangiogenesis (MVD), the EnVision two-step method was performed according to the manufacturer's instructions using EnVision+/ HRP polymer (Dako, Cytomation). The primary antibodies were anti-CD34 monoclonal antibody (clone QBEnd10, DAKO Cytomation, Denmark) and the anti-CD31 monoclonal antibody (clone JC70A, DAKO Cytomation, Denmark), both diluted as 1:50 in PBS. The sections were pre-treated for 20 minutes with heat-induced epitope retrieval (MW) in target retrieval solution High pH (Dako Cytomation) and incubated 30 minutes at $25^{\circ} \mathrm{C}$ with the primary antibodies. 
After incubation with the polymeric detection system (for 30 minutes at $25^{\circ} \mathrm{C}$ ), visualization was performed with $\mathrm{DAB}$ and counterstaining with Harris Hematoxylin. Negative control was obtained by skipping the primary antibodies, and the positive controls were the slides provided by the Dako reagent kit.

MVD was assessed by using initially low-power magnification for the identification of the vascular "hot spots". After that, the vessels were counted in three different fields at a high-power magnification $(400 \times)$ and an average was calculated for each case - mean \pm standard deviation (SD). The isolated reactive endothelial cells or groups of endothelial cells separated by the adjacent microvessels were considered as quantifiable individual vessels. Visible lumens or the presence of associated red blood cells were not obligatory. All MVD data and results have been reported further on as the average number of vessel / 400× microscopic filed \pm standard deviation of the mean.

Written informed consent of all patients was obtained. The study was approved by the Ethics Committee of the University of Medicine and Pharmacy of Craiova.

\section{Statistical analysis}

Using the SPSS statistical software package was performed the statistical analysis. Comparing two groups' data was done with the Student's $t$-test: Two-Sample Assuming Unequal Variances and chi-test used to detect the relationship between the presence of vascular and perineural invasion, and MVD with the clinicopathological characteristics. A value of $p<0.05$ was considered statistically significant.

\section{Results}

\section{Vascular and neural invasion}

For all 367 patients of this study, the mean age was of $65 \pm 10$ years, ranging from 30 to 87 years. According to the genders, there were 121 female and 246 male patients, with a sex ratio female: male of 2.03 .

According to the TNM stage: 71 (19.35\%) cases were in the stages I or II, while 296 $(80.65 \%)$ cases were classified as stage III or IV. According to the classification of Lauren, the diffuse type of gastric carcinoma was found in $77(20.98 \%)$ cases, the intestinal type, in 285 (77.66\%) cases and 5 cases were included others types of gastric carcinoma (1.36\%). Histological grading of gastric carcinomas revealed that $6.27 \%$ of patients ( 23 cases) had G1 grade, $35.97 \%$ of patients (132 cases) had G2 grade and $57.77 \%$ of patients (212 cases) had G3 grade.

Blood vessel invasion was found positive in a 85 cases $(23.16 \%)$. Correlating the tumor invasion into vascular spaces with patients' sex, age and disease stage, we observed that vascular positivity was more common in females $(28.1 \%$ women vs. $20.73 \%$ men, $\mathrm{p}>0.05)$ and in patients over 50 years $(23.19 \%$ vs. $22.86 \%$ for patients $\leq 50$ years, $\mathrm{p}>0.05$ ). The blood vessel invasion was significant associated with advanced stages (stages III and IV $26.69 \%$ vs. $8.45 \%$ stages I and II, $\mathrm{p}<0.01)$ and high grade carcinomas $(29.25 \%$ G3 vs. $14.84 \%$ G1-G2, $\mathrm{p}<0.01)$. No significant statistical relationship were found between blood vessel invasion and the histological type $(\mathrm{p}>0.05)$.

Lymphatic invasion was observed in 186 cases from 367 (50.68\%). The relationship between the tumor invasion in the lymphatic vessels and the patients' gender, age and disease stage, showed that the presence of invasion was more common in women $(57.02 \%$ vs. $47.56 \%$ men; $\mathrm{p}>0.05$ ), in patients under or equal to 50 years ( $60 \%$ vs. $49.7 \%$ in cases over 50 years; $p>0.05)$ and in the advanced stages $(61.15 \%$ stage III-IV vs. $7.04 \%$ stage I-II; $\mathrm{p}<0.001)$. No significant statistical correlations were found between lymphatic vessel invasion and the histological type and grade of carcinomas ( $\mathrm{p}>0.05$ ).

Neural invasion was revealed in 119 cases $(32.43 \%)$ of gastric carcinomas. Comparing the 
presence of peri or intraneural invasion with the patients' gender, age and stage of disease, we noticed that the neural invasion was more common in elderly patients over 50 years $(32.83 \%$ vs. $28.57 \%$ patients under or equal to 50 years; $\mathrm{p}>0.05)$ and significantly more frequent in women $(40.5 \%$ vs. $28.46 \%$ men; $<<0.05)$ and in more advanced stages $(36.82 \%$ stage III-IV vs. $14.08 \%$ stage I-II; $\mathrm{p}<0.001)$. Regarding the neural invasion, there were significant differences between the histological type and degree of tumor differentiation, being more common in diffuse-type gastric tumors (42.86\% vs. $30.18 \%$; $\mathrm{p}<0.05)$, and in poorly differentiated gastric carcinoma $(\mathrm{p}<0.05)$. (Table I, Figure 1)

\section{Microvessel density}

For the 28 patients evaluated immunohistochemical for MVD, the mean age was of 58.79 years with $\mathrm{SD}=14.35$ (range from 30 to 87 years). The cut-off point used in further statistical analysis was of 50 years.
According to the TNM stage, which was assessed from 16 patients with surgical gastric cancer samples, only six $(37.5 \%)$ cases were in the first two stages, while $10(62.5 \%)$ cases were classified as stage III or IV.

Among the all 28-gastric cancer samples, the gastric carcinoma of diffuse type was found in 10 cases $(35.71 \%)$ and the intestinal type, in 18 $(64.29 \%)$ cases. Histological grading of carcinoma revealed that six $(21.43 \%)$ patients had G1 grade (well differentiated), four (14.29\%) patients had G2 grade (moderately differentiated) and $18(64.29 \%)$ patients had G3 grade (poorly differentiated).

The MVD for 28 tumors expressed as CD31-vessel density has varied from 12 to 27 and the mean MVD value of $19.1 \pm 4.25 \mathrm{SD}$. When 19 mean value for MVD CD31 was chosen as the cut-off point for discrimination of 28 patients, 20 patients were included as low MVD CD31 and eight as high MVD CD31.

Table I. Correlations of clinico-morphological parameters with vascular and neural invasion

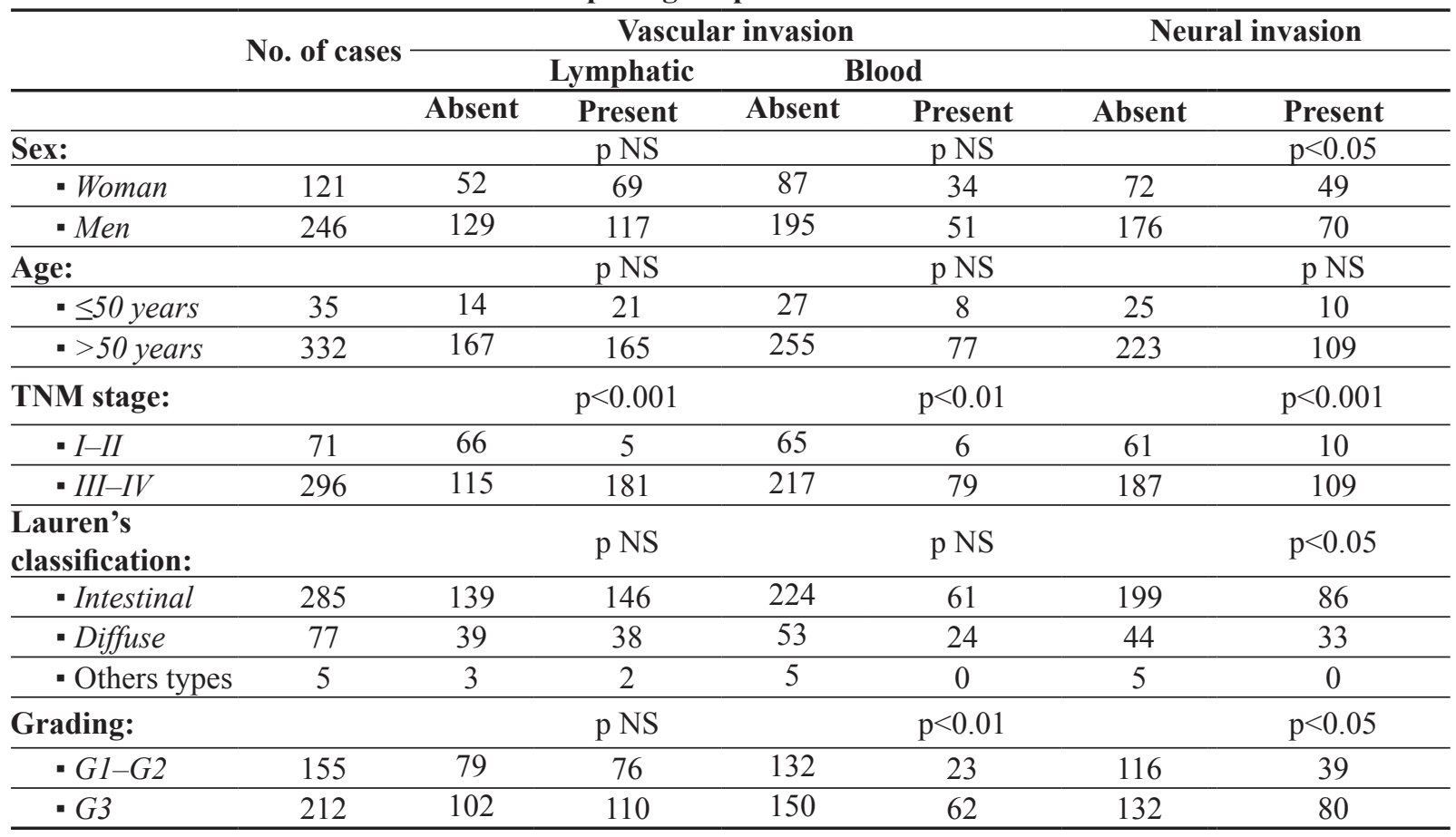


a)
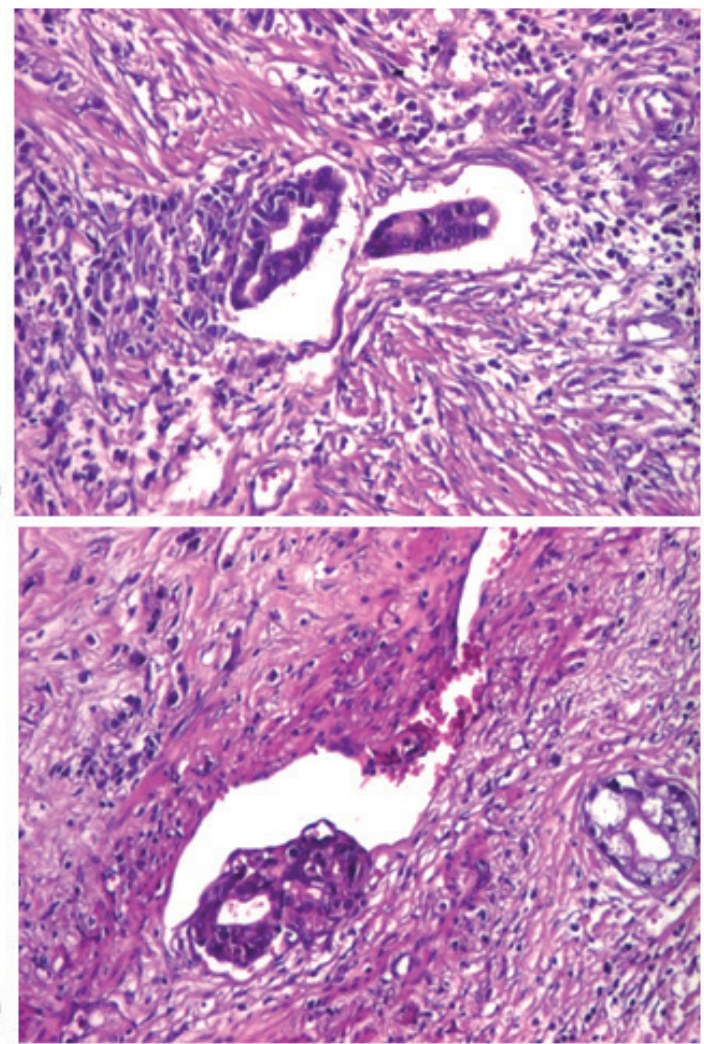

e)

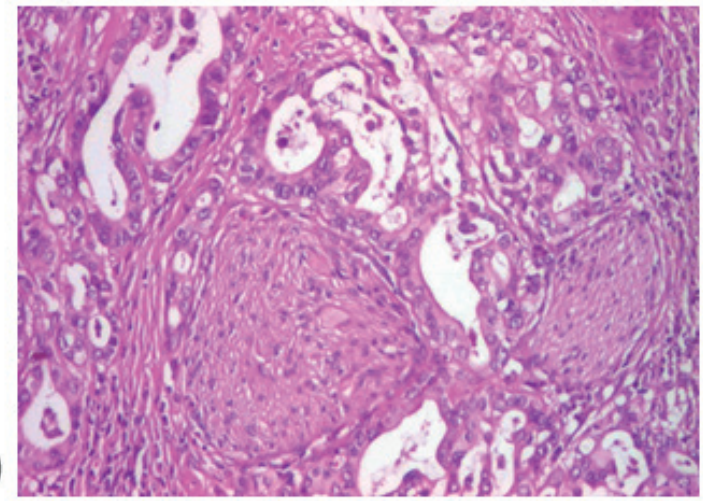

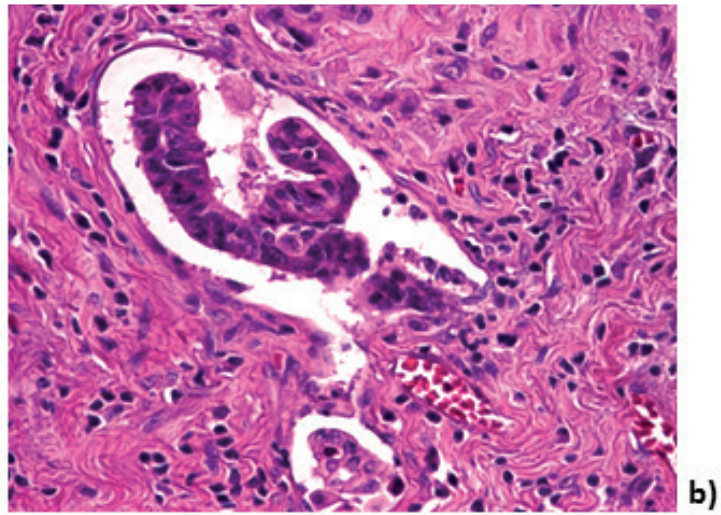
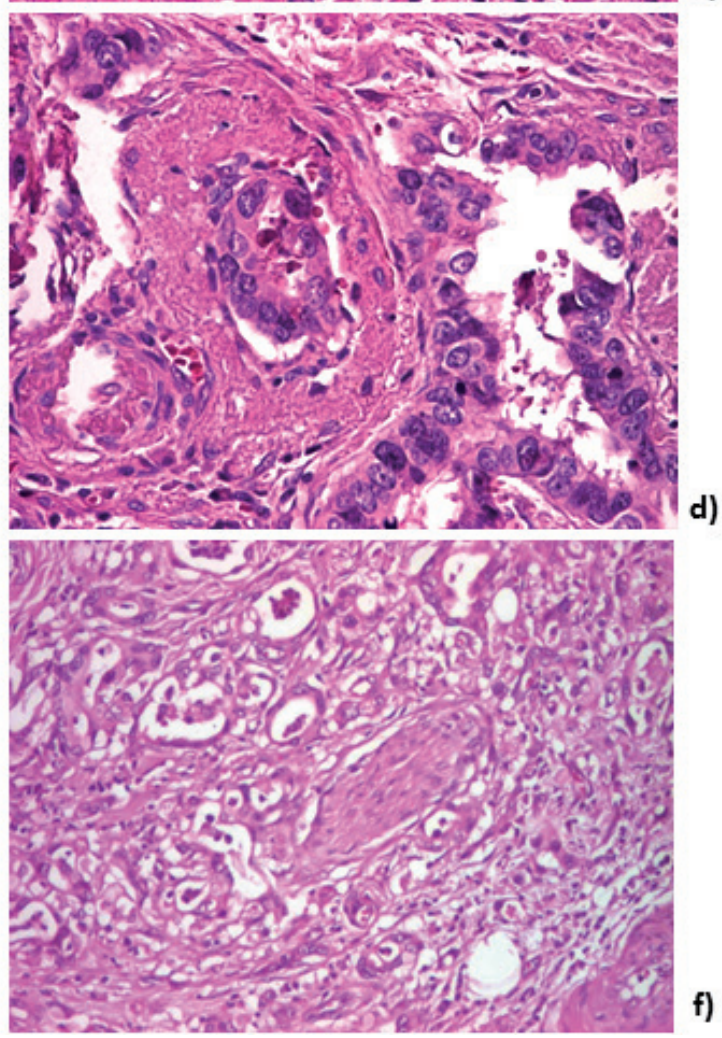

f)

Figure 1. a. Lymphatic vessel invasion (H\&E staining, $x 100)$; b. Lymphatic vessel invasion (H\&E staining, x200); c. Blood vessel invasion (H\&E staining, x100); d. Blood vessel invasion (H\&E staining, x200);

e. Perineural invasion (H\&E staining, $x 100)$; f. Perineural invasion (H\&E staining, $x 100)$

In addition, the MVD expressed as CD34vessel density ranged from 16 to 45 , and the mean MVD value was 28.6 \pm 8.6 SD. When a mean MVD value of 29 for CD34 was chosen as the cut-off, 16 patients were included as low MVD CD34 and 12 as high MVD CD34.
This study revealed a strong correlation between tumor angiogenesis detected using CD34 and tumor type and tumor grade of gastric carcinomas. MVD values were higher in the diffuse type of gastric cancer compared to the intestinal type (33.4 \pm 9.18 vs. $26 \pm 7.29 ; p<0.05)$. In G1 and 
G2 differentiated tumors, MVD was significantly lower compared to the group of G3 differentiated cancers $(23.8 \pm 6.55$ vs. $31.3 \pm 8.6 ; p<0.05)$.

We found a statistically meaningful difference of the mean CD34 MVD values and the TNM stage and gender, MVD being higher in stages III/IV than in stages I/II $(28.2 \pm 5.22 \mathrm{vs}$. $21.7 \pm 2.25 ; p<0.01)$, in women than in men (37 \pm 4.6 vs. $27.2 \pm 8.4 ; p<0.05)$ and patients under or equal to 50 years $(37 \pm 4.7$ vs. $26.4 \pm 8.07$, patients over 50 years; $\mathrm{p}<0.01$ )

All the resulting data MVD associations were the result of CD34 interpretations, whereas the CD31 expression was less associated with any of the clinic-pathological parameters, except the histological grade of the tumor. The CD31 MVD revealed significant differences according to the grading of carcinomas, being highest in G3 gastric carcinomas $(20.2 \pm 4.47$ vs. $17.2 \pm 3.16$; $\mathrm{p}<0.05)$. (Table II, Figure 2)

\section{Discussion}

The evolution and prognosis of patients diagnosed with gastric carcinoma are influenced by two important factors: the depth of the tumor in the stomach wall and the metastasis which can be present or absent in the lymph nodes. By establishing also the status of distant metastasis, TNM system represents the most widely used system for assessing patient outcomes, as it brings several prognostic information $[14,15]$.

A proper identification of the parameters which determine a decreased prognosis of gastric cancer could help in establishing more aggressive adjuvant therapy protocols.

However, the prognosis varies among the patients in same stage and therefore, it is necessary to consider other prognostic factors. Of these, lympho-vascular and perineural invasion appear to be the potentially necessary to ensure much more relevant information about the clinical evolution and therapeutic strategy to the patients diagnosed with gastric cancer [16].

In our study, blood vascular invasion was found in 85 from 367 cases of gastric cancer, $(23.16 \%)$, and the lymphatic invasion in 186 cases $(50.68 \%)$. Our results are in agreement with those from the current literature [17].

Table II. Correlations of clinico-morphological parameters with microvessel density detected by immunohistochemistry (MVD)

\begin{tabular}{|c|c|c|c|c|c|}
\hline & No. of cases & MVD CD31 \pm SD & p value & MVD CD34 \pm SD & p value \\
\hline \multicolumn{6}{|l|}{ Sex: } \\
\hline - Woman & 4 & $20 \pm 6.9$ & \multirow{2}{*}{$\mathrm{p}$ NS } & $37 \pm 4.62$ & \multirow{2}{*}{$\mathrm{p}<0.05$} \\
\hline - Men & 24 & $19 \pm 3.8$ & & $27.25 \pm 8.40$ & \\
\hline \multicolumn{6}{|l|}{ Age: } \\
\hline - $\leq 50$ years & 6 & $21.3 \pm 3.6$ & \multirow{2}{*}{$\mathrm{p}$ NS } & $37 \pm 4.7$ & \multirow{2}{*}{$\mathrm{p}<0.01$} \\
\hline - $>50$ years & 22 & $18.6 \pm 4.3$ & & $26.4 \pm 8.07$ & \\
\hline \multicolumn{6}{|l|}{ TNM stage*: } \\
\hline$\cdot I-I I$ & 6 & $19 \pm 1.79$ & \multirow{2}{*}{$\mathrm{p}$ NS } & $21.7 \pm 2.25$ & \multirow{2}{*}{$\mathrm{p}<0.01$} \\
\hline$\cdot I I I-I V$ & 10 & $18.2 \pm 3.85$ & & $28.2 \pm 5.22$ & \\
\hline \multicolumn{6}{|c|}{ Lauren's classification: } \\
\hline - Intestinal & 18 & $19.1 \pm 4,21$ & \multirow{2}{*}{$\mathrm{p}$ NS } & $26 \pm 7.29$ & \multirow{2}{*}{$\mathrm{p}<0.05$} \\
\hline - Diffuse & 10 & $19.2 \pm 4.54$ & & $33.4 \pm 9.18$ & \\
\hline \multicolumn{6}{|l|}{ Grading: } \\
\hline - $G 1-G 2$ & 10 & $17.2 \pm 3.16$ & \multirow{2}{*}{$\mathrm{p}<0.05$} & $23.8 \pm 6.55$ & \multirow{2}{*}{$\mathrm{p}<0.05$} \\
\hline - $G 3$ & 18 & $20.2 \pm 4.47$ & & $31.3 \pm 8.62$ & \\
\hline
\end{tabular}



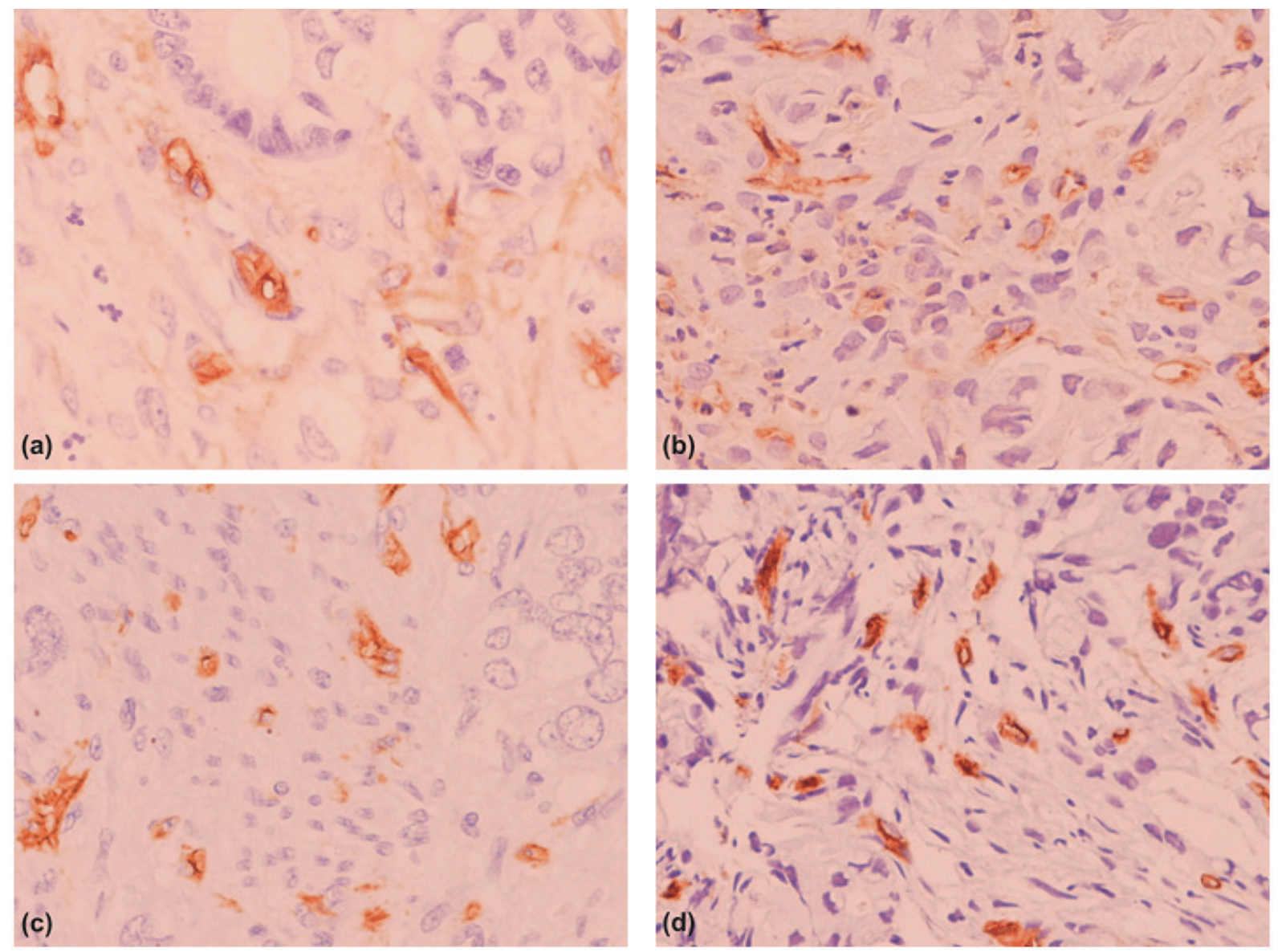

Figure 2. a. CD31 low MVD, intestinal type G1 carcinoma, $\times 400 ; b$. CD31 high MVD, diffuse type carcinoma, $\times 400$; c. CD34 low MVD, intestinal type G2 carcinoma, $\times 400$; d. CD34 high MVD, intestinal type carcinoma $\mathbf{G 3}, \times \mathbf{4 0 0}$.

The prognostic meaning of tumor invasion into the blood and lymphatic vessels was investigated in several studies. Thus, Gabbert et al., into a retrospective study on a number of 529 cases of gastric cancer, have noticed that patients with the lympho-vacular invasion had a much lower survival rate compared to patients without invasion, demonstrating that that vascular blood and limphatic invasion are independent prognostic factors [17]. Similar results were obtained in other studies, showing that blood and lympho-vascular invasion can be useful markers to estimate the recurrence and prognosis of patients with gastric cancer $[5,16]$.
Also, tumor invasion into vascular or lymphatic system is closely related with a progressive decline in the degree of tumor differentiation, lymph node metastases and with more advanced stages [17, 18]. In our study we have found a statistically significant difference between lympho-vascular invasion in different stages of disease $(61.15 \%$ in stage III-IV vs. $7.04 \%$ in stage I-II; $p<0.001)$; there were no significant differences for the other clinical and morphological parameters analyzed, and we observed that the presence of invasion was more common in women ( $57 \%$ vs. $47.6 \%$ men; $p>0.05)$, and in patients under or equal to 50 years $(60 \%$ vs. $49.7 \%$ 
in cases over 50 years; $\mathrm{p}>0.05$ ). By comparison, the blood vessel invasion was significant associated with advanced stages (stages III and IV $26.69 \%$ vs. $8.45 \%$ stages I and II, p <0.01) and also with high grade carcinomas $(29.25 \% \mathrm{G} 3$ vs. 14.84\% G1-G2, $\mathrm{p}<0.01$ ).

The presence of vascular invasion were directly linked to the depth of invasion and the presence of lymph node and hepatic metastasis. In addition, the intratumoral angiogenesis was more pronounced in gastric cancers with vascular invasion [19]. In the study of Wang et al [20], the mean of MVD was much higher in patients with vascular invasion comparatively with the cases without vascular invasion, highlighting that angiogenesis is closely connected with the clinical aggressiveness of tumor.

In our study, we observed that perineural invasion in gastric carcinomas was $32.43 \%$ (119 cases). These results are consistent with the findings of other studies, in which the positivity of perineural invasion of gastric cancer varies between $26 \%$ and $73 \%[16,21,22]$.

In his work, Selçukbiricik et al. studied the influence of perineural invasion on the survival of patients with gastric cancer, this being associated significantly with lymph node metastases, advanced disease $(p<0.0001)$ and with the depth of invasion into the gastric wall and lymph-vascular invasion [22]. The survival of the patients with perineural invasion is much lower compared to that of those without invasion, thus having a more reserved prognosis. In contrast, they didn't find an association between perineural invasion and sex, age, tumor location or the histological type of tumor [22]. Similarly, Kooby demonstrated that neural invasion correlates with tumor size and $\mathrm{T}$ stage and can be use as a marker of advanced disease [23].

In our study, when we compared the presence of peri or intraneural invasion depending on the patients' gender, age and stage of disease, we noticed that it was significantly more fre- quent in women $(40.5 \%$ vs. $28.5 \%$ men; $\mathrm{p}<0.05)$ and in more advanced stages $(36.8 \%$ stage III-IV vs. $14.1 \%$ stage I-II; $\mathrm{p}<0.001)$. Also there is a statistically appreciable association with the histological type and grade, the neural invasion being more common in diffuse-type gastric tumors $(p<0.05)$ and in poorly differentiated tumors $(\mathrm{p}<0.05)$.

In studies conducted by Duraker et al [24], Scartozzi et al [16] and Tianhang et al [21], was observed that tumor invasion into the nerves represents an independent prognostic factor for gastric cancer. It is considered that this is frequently associated with tumor recurrence after surgery or with early metastasis of gastric cancers. The presence of neural invasion adversely affects the prognosis of patients diagnosed with gastric cancer and treated with radical surgery [16, 21, 24].

Identification of the tumor metastasis in the vascular and neural system allowed establishing, in the same subgroup of cases which have a low risk of recurrence, the patients with different clinical outcomes, thereby providing an efficient instrument in selecting the right therapeutically method and for stratification of the prognosis in these cases [16].

The formation of new blood vessels from the malignant surrounding environment, represents an essential factor in metastasis and tumor progression. The process of angiogenesis is the outcome of an imbalance between positive and negative regulators of neo-vascularization. The angiogenesis was first discovered by Folkman, who observed that the tumor development is dependent on the formations of new blood vessel. Therefore, many regulators of angiogenesis have been discovered and studied. [25].

The CD34 antigen labels more microvessels than CD31, being thus more useful in determination of tumor angiogenesis. There are studies which compared the expression of endothelial markers CD31 and CD34, to asses the angio- 
genesis, and the authors recommend the use of CD34, this marker being more efficient $[10,26]$.

In our study, we observed that in gastric carcinomas, angiogenesis, measured by the expression of CD34, is strong positive associated with Lauren's classification $(p<0.05)$, TNM stage $(p<0.01)$ and histological grade $(p<0.05)$. The CD34 MVD average of intestinal type tumors is lower than in diffuse type gastric carcinomas (26 \pm 7.3 vs. $33.4 \pm 9.18)$.

Diffuse carcinoma is a histological form associated with an intense neoangiogenesis activity. It is know that patients with diffuse type gastric cancer have a lowest outcome, and this is why the assessment of angiogenesis is very important in assessment of individual survival and for the selection of patients with increased risk of recurrence $[9,26]$. Our results suggest that the higher metastatic potential of gastric adenocarcinoma is observed in diffuse type, because of the more intense angiogenesis, compared with the intestinal type tumors.

We observed a proportional increase of CD34 MVD and TNM stage. The mean CD34 MVD value was of $28.2 \pm 5.22$ for the advanced gastric cancers, stages III and IV. Compared to the first two stages of gastric carcinomas, which had a mean CD34 MVD of $21.7 \pm 2.25$, advanced stages had a significantly higher MVD $(p<0.01)$. Zhou et al demonstrated that tumor angiogenesis, and consequently, the MVD is more pronounced with tumor invasiveness, being influenced by the clinical stage of the tumor, significantly higher in advanced gastric cancer (stage III and IV) [27]. The MVD can be considered an independent marker in the evolution of gastric cancer and in determining the prognosis of patients affected by this malignancy, whereas, the higher MVD value is, the higher is the risk of expansion and metastasis, and more advanced is the disease stage. These results were observed in several studies, which have revealed a directly proportional relationship between the value of
MVD and the risk of tumor growth, lymphatic and distant metastasis of gastric cancer, especially in the liver and peritoneum [28, 29].

We have also found a tight association between the grade of carcinomas and the quantification of angiogenesis. As the tumor dedifferentiation, may be observed an increase of intratumoral newly formed blood vessels with an accentuation of angiogenesis. The G1-G2 tumors had an average value of $23.8 \pm 6.55$, significantly lower compared to the average values registered in the G3 carcinomas $(31.3 \pm 8.62, p<0.05)$. Our results are in concordance with the results of other authors [26, 29, 30].

\section{Conclusions}

Vascular invasion, neural invasion and CD 34 MVD are significantly associated with diffuse type of gastric carcinoma, poor differentiated G3 carcinomas and advanced stages of the disease, demonstrating that with the progression of the malignancy, there is an increasing risk of tumor development and metastasis, and the affected patients have a worse prognosis.

Immunohistochemical assessment of MVD based on CD34 staining is more sensitive than that based on CD31 staining.

Blood vessel invasion, neural invasion and CD34 MVD play a significant role in tumors biological behavior and they can be used as important prognostic parameters which describes the aggressiveness of gastric carcinomas.

\section{Abbreviations}

H\&E - Hematoxylin \& Eosin

MVD - microvessel density

SD - standard deviation

\section{References}

1. Accetta AC, Manso JE, Mello EL, Paiva RK, Castro Ldos S, Accetta P. Type IV Borrmann gastric adenocarcinoma: analysis of curative resection results. Rev Col 
Bras Cir. 2011; 38(4): 237-44. DOI: 10.1590/S010069912011000400007

2. Adachi Y, Yasuda K, Inomata M, Sato K, Shiraishi N, Kitano S. Pathology and prognosis of gastric carcinoma: well versus poorly differentiated type. Cancer. 2000; 89(7): 1418-24. DOI:10.1002/1097-0142(20001001)89:7<1418::AIDCNCR2>3.0.CO;2-A

3. Greene FL, Page DL, Fleming ID, Fritz A, Balch CM, Haller DG, et al. AJCC Cancer Staging Handbook 6th Edition. American Joint Committee on Cancer. 2002; 111-9. DOI: 10.1007/978-1-4757-3656-4

4. Minsky B, Cohen AM. Blood vessel invasion in colorectal cancer-an alternative to TNM staging? Ann Surg Oncol. 1999; 6: 129-130. DOI: 10.1007/s10434999-0129-x

5. Hyung WJ, Lee JH, Choi SH, Min JS, Noh SH. Prognostic impact of lymphatic and/or blood vessel invasion in patients with node-negative advanced gastric cancer. Ann Surg Oncol. 2002; 9: 562-7. DOI: $10.1007 / \mathrm{BF} 02573892$

6. Batsakis JG. Nerves and neurotropic carcinomas. Ann Otol Rhinol Laryngol. 1985; 94: 426-7.

7. Liebig C, Ayala G, Wilks JA, Berger DH, Albo D. Perineural invasion in cancer: a review of the literature. Cancer. 2009; 115: 3379-91. DOI: 10.1002/cncr.24396

8. Folkman J, Shing Y. Angiogenesis. J Biol Chem. 1992, 267(16): 10931-4.

9. Suzuki S, Dobashi Y, Hatakeyama Y, Tajiri R, Fujimura $\mathrm{T}$, Heldin $\mathrm{CH}$, et al. Clinicopathological significance of platelet-derived growth factor (PDGF)-B and vascular endothelial growth factor-A expression, PDGF receptor- $\beta$ phosphor-ylation, and microvessel density in gastric cancer. BMC Cancer. 2010; 10: 659. DOI: 10.1186/1471-2407-10-659

10. de la Taille A, Katz AE, Bagiella E, Buttyan R, Sharir $\mathrm{S}$, Olsson CA, et al. Microvessel density as a predictor of PSA recurrence after radical prostatectomy. A comparison of CD34 and CD31. Am J Clin Pathol. 2000; 113(4): 555-62. DOI: 10.1309/02W2-KE50-PKEFG2G4

11. Choi YH, Choi KC, Park YE. Relationship of transforming growth factor beta 1 to angiogenesis in gastric carcinoma. J Korean Med Sci. 1997; 12(5): 427-32.

12. Zhao HC, Qin R, Chen XX, Sheng X, Wu JF, Wang $\mathrm{DB}$, et al. Microvessel density is a prognostic marker of human gastric cancer. World J Gastroenterol. 2006; 12(47): 7598-603.

13. Lauren PA. The two histological main types of gastric carcinoma: diffuse and so-called intestinal-type carcinoma. An attempt at a histo-clinical classification. Acta Pathol Microbiol Scand. 1965; 64:31-49.

14. American Joint Committee on Cancer. Stomach. AJCC Cancer Staging Manual. 6th ed. New York, NY: Springer, 2002; 99-106.
15. Sobin LH, Wittekind CH, eds. TNM Classification of Malignant Tumors. 6th ed. New York: John Wiley \& Sons; 2002.

16. Scartozzi M, Galizia E, Verdecchia L, Berardi R, Graziano F, Catalano V, et al. Lymphatic, blood vessel and perineural invasion identifies early-stage high-risk radically resected gastric cancer patients. $\mathrm{Br} \mathrm{J}$ Cancer. 2006; 95(4): 445-9. DOI: 10.1038/sj.bjc.6603286

17. Gabbert HE, Meier S, Gerharz CD, Hommel G. Incidence and prognostic significance of vascular invasion in 529 gastric-cancer patients. Int. J. Cancer. 1991; 49 (2): 203-7. DOI: 10.1002/ijc.2910490210

18. del Casar JM, Corte MD, Alvarez A, García I, Bongera M, González LO, et al. Lymphatic and/or blood vessel invasion in gastric cancer: relationship with clinicopathological parameters, biological factors and prognostic significance. J Cancer Res Clin Oncol. 2008; 134(2): 153-61. DOI: 10.1007/s00432-007-0264-3

19. Maehara Y, Kabashima A, Koga T, Tokunaga E, Takeuchi H, Kakeji Y, at al. Vascular invasion and potential for tumor angiogenesis and metastasis in gastric carcinoma. Surgery. 2000; 128(3): 408-16. DOI: 10.1067/ msy.2000.107265

20. Wang YD, Wu P, Mao JD, Huang H, Zhang F. Relationship between vascular invasion and microvessel density and micrometastasis, World J Gastroenterol. 2007; 13(46): 6269-73. DOI: 10.3748/wjg.13.6269

21. Tianhang L, Guoen F, Jianwei B, Liye M. The effect of perineural invasion on overall survival in patients with gastric carcinoma. J Gastrointest Surg. 2008; 12(7): 1263-7. DOI: $10.1007 / \mathrm{s} 11605-008-0529-4$

22. Selçukbiricik F, Tural D, Büyükünal E, Serdengeçti S. Perineural Invasion Independent Prognostic Factors in Patients with Gastric Cancer Undergoing Curative Resection. Asian Pacific J Cancer Prev. 2012; 13(7): 314952. DOI: 10.7314/APJCP.2012.13.7.3149

23. Kooby DA, Suriawinata A, Klimstra DS, Brennan MF, Karpeh MS. Biologic Predictors of Survival in Node-Negative Gastric Cancer. Ann Surg. 2003; 237(6): 828-37. DOI: 10.1097/00000658-20030600000011

24. Duraker N, Sişman S, Can G. The significance of perineural invasion as a prognostic factor in patients with gastric carcinoma. Surg Today. 2003; 33(2): 95-100. DOI: $10.1007 / \mathrm{s} 005950300020$

25. Folkman J. What is the evidence that tumors are angio-genesis dependent? J Natl Cancer Inst. 1990; 82(1): 4-6. DOI: 10.1093/jnci/82.1.4

26. Tenderenda M, Rutkowski P, Jesionek-Kupnicka D, Kubiak R. Expression of CD34 in gastric cancer and its correlation with histology, stage, proliferation activity, p53 expression and apoptotic index. Pathol Oncol Res. 2001; 7(2): 129-34. DOI: 10.1007/BF03032579

27. Zhou YJ, Xiong YX, Wu XT, Shi D, Fan W, Zhou T, et al. Inactivation of PTEN is associated with increased 
angiogenesis and VEGF overexpression in gastric cancer. World J Gastroenterol. 2004; 10(21): 3225-9.

28. Joo YE, Sohn YH, Joo SY, Lee WS, Min SW, Park CH, et al. The role of vascular endothelial growth factor (VEGF) and p53 status for angiogenesis in gastric cancer. Korean J Intern Med. 2002; 17(4): 211-9.

29. Yang Q, Ye ZY, Zhang JX, Tao HQ, Li SG, Zhao ZS. Expression of matrix metalloproteinase-9 mRNA and vascular endothelial growth factor protein in gastric carcinoma and its relationship to its pathological features and prognosis. Anat Rec (Hoboken). 2010; 293(12): 2012-9. DOI: 10.1002/ar.21071

30. Du JR, Jiang Y, Zhang YM, Fu H. Vascular endothelial growth factor and microvascular density in esophageal and gastric carcinomas. World J Gastroenterol. 2003; 9(7): 1604-6. 